ORL 1997;59:I-V

\title{
Contents, Vol. 59, 1997
}

\section{No. 1}

No. 2

Obituary

Original Paper

1 Harold F. Schuknecht, 1917-1996

Nadol, J.B., Jr.

Original Paper

4 Polychromatic Labeling of Otoconia for the Investigation of Calcium Turnover

Takumida, M; Zhang, D.M.; Yajin, K.; Harada, Y. (Hiroshima)

10 Antibodies against Inner-Ear Proteins in the Sera of Patients with Inner-Ear Diseases

Suzuki, M. (Seta); Krug, M.S.; Cheng, K.-C. (Memphis, Tenn.); Yazawa, Y. (Seta); Bernstein, J. (Buffalo, N.Y.); Yoo, T.-J. (Memphis, Tenn.)

18 Morphometric Evaluation of the Infralabyrinthine Approach to the Internal Auditory Canal Balyan, F.R. (Piacenza/Ankara); Caylan, R. (Piacenza/Trabzon); Asian, A.; Titiz, A.; Taibah, A.; Russo, A.; Sanna, M. (Piacenza)

23 Evaluation of Performance with the COMBI 40 Cochlear Implant in Adults: A Multicentric Clinical Study

Helms, J.; Müller, J.; Schön, F.; Moser, L. (Würzburg); Arnold, W,; Janssen, T. (Munich r.d.

Isar); Ramsden, R. (Manchester); von Ilberg, C; Kiefer, J.; Pfennigdorf, T. (Frankfurt); Gstöttner, W.; Baumgartner, W,; Ehrenberger, K. (Vienna); Skarzynski, H. (Warsaw); Ribari, O.

(Budapest); Thumfart, W.; Stephan, K. (Innsbruck); Mann, W,; Heinemann, M.; Zorowka, P.; Lippert, K.L. (Mainz); Zenner, H.P.; Bohndorf, M. (Tubingen); Hüttenbrink, K.; MüllerAschoff, E.; Hofmann, G. (Dresden); Freigang, B.; Begall, K.; Ziese, M.; Forgbert, O. (Magdeburg); Häusler, R.; Vischer, M.; Schlatter, T. (Bern); Schlöndorff, G,; Korves, B; Döring, H. (Aachen); Gerhardt, H.J.; Wagner, H. (Berlin Charité); Schorn, K.; Schilling, V.; Baumann, U,; Kastenbauer, E. (Munich Grosshadern); Albegger, K.; Mair, A. (Salzburg); Gammert, Ch.; Mathis, A. (Luzern); Streitberger, Ch. (Bozen); Hochmair-Desoyer, I. (Innsbruck) 36 Olfactory Threshold after Nasal Allergen Challenge

Hinriksdóttir, I. (Skövde); Murphy, C. (San Diego, Calif.); Bende, M. (Skövde) 39 One-Week Use of Oxymetazoline Nasal Spray in Patients with Rhinitis medicamentosa 1 Year after Treatment Graf, P.; Hallén, H. (Stockholm) 45 Laser-Assisted Uvulopalatoplasty for Habitual Snoring without Sleep Apnea: Outcome and Complications Ikeda, K.; Oshima, T.; Tanno, N.; Ogura, M.; Shimomura, A.; Suzuki, H.; Takasaka, T. (Sendai) 
50 Rhinostereometry and Laser Doppler Flowmetry in Human Nasal Mucosa: Changes in Congestion and Microcirculation during Intranasal Histamine Challenge

Grudemo, H; Juto, J.-E. (Stockholm)

Case Reports

67 Electrically Evoked Auditory Brainstem Response by Direct Electrical Stimulation to the

Cochlear Nerve in Acoustic Neuroma Patients

Tanaka, H.; Komatsuzakí, A.; Okuno, H. (Tokyo)

73 Iron Deficiency Anemia and Hearing

Ozturan, O. (Malatya); Henley, CM.; Littman, T.A.; Jenkins, H.A. (Houston, Tex.)

79 Effectiveness of Hyperbaric Oxygen Therapy in Patients with Acute and Chronic Cochlear

Disorders

Kau, R.J.; Sendtner-Gress, K. (Munich); Ganzer, U. (Düsseldorf); Arnold, W. (Munich)

84 Middle Ear Overpressure Treatment of Endolymphatic Hydrops in Guinea Pigs

Sakikawa, Y.; Kimura, R.S. (Boston, Mass.) 91 Regeneration of Olfactory Mucosa in Mice after Inhalation Exposure to Perchloroethylene

Suzaki, H. (Tokyo); Aoki, A. (Tokorozawa-shi); Nomura, Y. (Tokyo)

97 No Epstein Barr and Cytomegalovirus DNA Found in Salivary Gland Tumours

Kärjä, V.; Syrjänen, K. (Kuopio); Syrjänen, S. (Turku)

100 Videoendoscopic Biofeedback: A Simple Method to Improve the Efficacy of Swallowing

Rehabilitation of Patients after Head and Neck Surgery

Denk, D.-M.; Kaider, A. (Vienna)

106 Evaluation of TATI and CYFRA 21-1 in Patients with Head and Neck Squamous Cell

Carcinoma

Goumas, P.D.; Mastronikolis, N.S.; Mastorakou, A.N.; Vassilakos, P.J.; Nikiforidis, G.C.

(Patras)

Case Reports

115 Fistula of Stapes Footplate Caused by Pulsatile Cerebrospinal Fluid in Inner Ear

Malformation

Hoppe, F.; Hagen, R.; Hofmann, E. (Würzburg)

119 Circumferential Squamocellular Papilloma of the Cervical Esophagus, a Rare Cause of Dysphagia. A Case Report Sipilä, J.; Klemi, P. (Turku)

122 Bilateral Pseudo-lnternuclear Ophthalmoplegia in Myasthenia gravis

Ito, K.; Mizutani, J.; Murofushi, T.; Mizuno, M. (Tokyo)

126 Announcements

57 Non-Recurrent Laryngeal Nerve: Identification during Thyroid Surgery

Srinivasan, V.; Premachandra, D.J. (Great Yarmouth)

60 Primary Localized Nodular Tongue Amyloidosis Associated with Sjögren's Syndrome

Haraguchi, H,; Ohashi, K.; Yamada, M.; Hasegawa, M.; Maeda, S.; Komatsuzaki, A. (Tokyo)

Pathology Spot

64 Osteoma of the Promontory: A Case Report

Ramírez-Camacho, R.; Pinilla, M.; García-Berrocal, J.R. (Madrid)

Book Review Announcements

KARGEH

E-Mail karger@,karger.ch Fax+41 613061234 http://www.karger.ch

(C) 1997 S. KargerAG, Basel

The list of contents is available at: http://www.karger.ch/journals/orl/orlcont.htm 
III

No. 3

No. 4

Original Paper

127 Glycerol Administration Modulates the Pattern of the

3-Fucosyi-N-Acetyl-Lactosamine (CD15) Epitope in the Adult Guinea Pig Inner Ear

Meyer zum Gottesberge, A.M.; Mai, J.K. (Düsseldorf)

131 Ultrastructural Localization of Glutamate and Aspartate Immunoreactivities in Gerbil Inner Hair Cells

Liu, T.-C. (Taipei)

135 Longitudinal Non-Invasive Perilymphatic Pressure Measurement in Patients with Ménière's Disease

Rosingh, H.J.; Wit, H.P.; Suiter, A.M.; Albers, F.W.J. (Groningen)

141 The Influence of Aging on Auditory Brainstem Response and Electrocochleography in the Elderly

Oku, T.; Hasegewa, M. (Tokyo)

147 Etretinate-lnduced Malformation of the First Two Branchial Arches: Differential Staining and Microdissection Study of Embryonic Cartilage

Jacobsson, C; Granström, G. (Gothenburg)

155 Comparison of Effectiveness of Maneuvers and Medication in the Treatment of Benign Paroxysmal Positional Vertigo

Itaya, T.; Yamamoto, E. (Kobe); Kitano, H.; Yazawa, Y.; Kitajima, K. (Shiga)

159 Electromyographic Analysis of Profound Facial Nerve Paralysis following Acoustic

Neuroma Resection

Kunihiro, T.; Kanzakí, J.; Yoshihara, S.; Satoh, Y.; Shiobara, R.; Abe, S. (Tokyo)

166 Morphological Distribution of Middle-Ear Epithelium in the Wistar Rat: A Functional

Hypothesis

Scarano, E,; Paludetti, G.; Frusoni, F.; Deli, R.; Maurizi, M. (Rome)

170 Extracellular ATP Modulates Ion Transport via P2 $\gamma$ Purinoceptors in a Middle-Ear Epithelial Cell Line

Yen, P.-T. (Paris/Taipei); Herman, P.; Van Den Abbeele, T. (Paris); Tan, C.-T. (Taipei);

Bordure, P. (Nantes); Marianowski, R.; Friedlander, G.; Tran Ba Huy, P. (Paris)

176 Histiocytic Necrotizing Lymphadenitis (Kikuchi's Disease) of the Cervical Lymph Nodes

Kumar, B.N.; Walsh, R.M.; Walter, N.M.; Little, J.T. (Stoke on Trent)

Case Reports

179 Glomangioma of the Nasal Cavity. Case Report and Literature Review

Arens, C; Dreyer, T.; Eistert, B.; Glanz, H. (Giessen) 182 Laryngeal Neurinoma. A Case Report and Review Fini-Storchi, I.; Frosini, P. (Florence)

186 Announcements

Original Paper

187 Electron Probe X-Ray Microanalysis of Otoconia in the Guinea Pig Inner Ear

Takumida M.; Zhang D.M. (Hiroshima) 193 The Morphological Differences of Stereocilia and

Cuticular Plates between Type-I and Type-1l Hair Cells of Human Vestibular Sensory Epithelia

Morita, I.; Komatsuzaki, A. (Tokyo); Tatsuoka, H. (Chiba) 198 Clinical Testing of the StatolithOcular Reflex 
Kingma, H. (Maastricht) 209 Selective Chemical Vestibulectomy. Preliminary Results Ecke, U. (Mainz); Begall, K. (Magdeburg); Amedee, R.G.; Norris, C.H. (New Orleans, La.); Mann, W.J. (Mainz)

215 Molecular Basis of Type II Collagen Autoimmune Disease:

Observations of Arthritis, Auricular Chondritis and Tympanitis in Mice

Fujiyoshi, T. (Fukuoka); Cheng, K.-C; Krug, M.S. (Memphis, Tenn.); Yoo, T.-J. (Taejon)

Case Reports

230 Temporal Bone Pathology of a Patient with Cochlear Implant

Nakai, Y.; Sakashita, T.; Kubo, T,; Yamane, H.; Masutani, H; Kato, A.; Iguchi, H.; Takayama, M. (Osaka); Ito, J. (Shiga)

235 Laryngeal Zoster with Unilateral Laryngeal Paralysis

Nishizaki, K.; Onoda, K; Akagi, H.; Yuen, K; Ogawa, T.; Masuda, Y. (Okayama)

238 Sternocleidomastoid Muscle-Clavicle Myoosseous Flap for Single-Stage Reconstruction of Postoperative Tracheal Defects in Patients with Invasive Thyroid Tumor. Three Case Reports Asakura, K; Shido, F.; Harabuchi, Y.; Shirasaki, H.; Wakashima, J.; Kataura, A. (Sapporo)

IV

ORLVol. 59, 1997

Contents

No. 5

Original Paper

243 A Novel, Simple Organotypic Culture Method to Study the Organ of Corti from the Neonatal Gerbil

Liu, T.-C. (Taipei); He, D.Z.Z.; Lin, X. (Evanston, 111.)

248 Alteration in Capillary Permeability of Horseradish Peroxidase in the Stria vascularis and

Movement of Leaked Horseradish Peroxidase after Administration of Furosemide

Naito, H.; Watanabe, K. (Saitama)

258 Image Analysis of Neurofilament Immunoreactivity in Human Spiral Ganglion

Hsu, W.-J. (Uppsala/Taipei); Anniko, M,; Kubo, T. (Uppsala); Huang, T.-S. (Taipei)

263 Effect of Streptomycin on the Otoconial Layer of the Guinea

Pig

Takumida, M.; Zhang, D.M.; Yajin, K.; Harada, Y. (Hiroshima)

269 Evaluation of the Vertical Semicircular Canal Function by the Pendular Rotation Test: A

Study on Patients with Benign Paroxysmal Positional Vertigo

Iida, M. (Isehara); Igarashi, M. (Isehara/Tokyo); Naitoh, A.; Ishida, K.; Endo, K.; Nomura, K.;

Sakai, M, (Isehara)

272 Intraoperative Measurements of Auditory-Evoked Potentials in Three Patients with Acoustic Neuroma

Tanaka, H; Komatsuzaki, A.; Hentona, H.; Noguchi, Y. (Tokyo)

277 Dehiscences of the Horizontal Segment of the Facial Canal in Otosclerosis

Tange, R.A.; de Bruijn, A.J.G (Amsterdam)

280 The Impact of the Measuring Distance on Laser-Doppler Measurements of the

Microcirculation in Human Nasal Mucosa. A Study of Rhinostereometry and Micromanipulator-

Guided Laser-Doppler Flowmetry

Grudemo, H,; Juto, J.-E. (Stockholm) 
286 Evaluation of the Role of Adenotonsillar Hypertrophy and Facial Morphology in Children with Obstructive Sleep Apnea

Shintani, T.; Asakura, K,; Kataura, A. (Sapporo)

Case Reports

292 The Possible Effect of Pregnancy on Ménière's Disease

Uchide, K.; Suzuki, N.; Takiguchi, T.; Terada, S.; Inoue, M. (Kanazawa)

296 Occult Thyroid Carcinoma Manifested as a Large Mediastinal Tumor

Ishibashi, T,; Yoshimoto, S.-i.; Tsunoda, R.; Fukaya, T.; Asai, M. (Tokyo)

Letters to the Editor

300 Investigation of the Nasopharyngeal Bacterial Flora in

Children with Otitis media with Effusion

Probst, R. (Basel)

301 Reply

Fujimori, I. (Yamanashi)

302 Comment to Reply

Probst, R. (Basel)

No. 6

Original Paper

303 Two Modes of Auditory Hair Cell Loss following Acoustic Overstimulation in the Avian Inner Ear

Nakagawa, T,; Yamane, H; Shibata, S.; Takayama, M.; Sunami, K.; Nakai, Y. (Osaka)

311 Localization of Nitric Oxide Synthase Isoforms (I, II and III) in the Endolymphatic Sac of the Guinea Pig

Takumida, M,; Zhang, D.M. (Hiroshima); Anniko, M. (Uppsala) 317 Immunoelectron-

Microscopic Localization of Synaptophysin in the Organ of Corti of the Guinea Pig

Heinrich, U.-R.; Maurer, J,; Backes, K.; Mann, W. (Mainz)

322 Measurement of [Ca2+]i and $[\mathrm{Na}+]$ i in Outer Hair Cells Isolated from Gerbil Cochlea

Liu, T.-C. (Taipei) 326 Evaluation of Hyperactive Caloric Responses in Patients with Inner Ear

Diseases

Ikeda, M. (Saitama); Watanabe, I. (Tokyo) 332 Far-Advanced Otosclerosis

Ghonim, M.R.; El-Degwy, A.A.; El-Sharabasy, A.E. (Mansoura)

Case Reports

336 Perineurioma: An Unusual Cause of an External Auditory Canal Polyp

Donnellan, R,; Rughubar, K.; Govender, D.; Chetty, R. (Congella) 339 Castleman's Disease: An

Unusual Cause of a Neck Mass

Kumar, B.N.; Jones, T.J.; Skinner, D.W. (Shrewsbury)

Book Reviews

Announcements

343 Author Index

345 Subject Index

Contents

ORLVol. 59, 1997

V 